\title{
Pengaruh Usia dan Masa Kerja Terhadap Produktivitas Kerja (Studi Kasus: PT. OASIS Water International Cabang Palembang)
}

\author{
Selvia Aprilyanti* \\ Program Studi Teknik Industri, Fakultas Teknik, Universitas Tridinanti Palembang \\ Email: selvia1704@univ-tridinanti.ac.id.
}

\begin{abstract}
Abstrak - Usia dan masa kerja merupakan faktor yang berkaitan langsung dengan produktivitas kerja. Usia dan masa kerja yang dirasakan oleh karyawan dapat menurunkan produktivitas ataupun meningkatkan produktivitas kerja karyawan. Penelitian ini dilakukan pada PT. Oasis Water International Cabang Palembang,bertujuan untuk mengetahui pengaruh usia dan lama masa kerja terhadap produktivitas kerja karyawan. Metode Analisis yang digunakan adalah metode regresi linier berganda menggunakan bantuan SPSS yang meliputi uji $t$ dan Uji F. Sebagai variabel bebas(independen), yaitu usia dan masa kerja, sedangkan variabel terikat (dependen) adalah produktivitas kerja. Hasil dari analisis data diperoleh bahwa variabel usia dan lama bekerja tidak berpengaruh positif terhadap produktivitas kerja, dimana nilai probabilitas uji $F$ nilai signifikansi untuk pengaruh usia dan masa kerja secara simultan terhadap produktivitas adalah sebesar 0,355 >0,05 dan nilai $F$ hitung 1,083 $F$ tabel 3,39, dan dari hasil analisis menggunakan koefisien determinasi diketahui bahwa faktor usia dan masa kerja hanya memiliki pengaruh sebesar 8,3 persen(\%) terhadap produktivitas kerja diperusahaan PT.Oasis Water International.
\end{abstract}

Kata kunci: Masa Kerja; Produktivitas; Regresi Linear Berganda; SPSS; Usia.

\begin{abstract}
Age and years of service are factors directly related to work productivity. Age and employment perceived by employees can decrease productivity or increase employee productivity. This research was conducted at PT. Oasis Water International Palembang Branch and aims to determine the influence of Age and Duration of employment on employee productivity. The number of sample is 27 respondents by using random sampling technique. Analysis method used is multiple linear regression method using SPSS aid which includes $t$ test and $F$ test. As independent variable (independent), that is age and work period, while dependent variable is work productivity. The result of data analysis showed that the variable of age and duration of work did not have a positive effect on work productivity, where the probability value of $F$ test of significance value for the effect of age and work period simultaneously to productivity was $0.355>0.05$ and $F$ value count $1.083<F$ table 3.39, and from the results of the analysis using the coefficient of determination known that the factor of age and employment only has an effect of 8.3 percent (\%) on work productivity in the company PT.Oasis Water International.
\end{abstract}

Keywords: Age; Multiple Linear Regression; Productivity; SPSS; Years of service

\section{PENDAHULUAN}

Perusahaan Air Minum Oasis Water International Cabang Palembang berperan besar dalam penyediaan air minum kemasan. Dengan meningkatnya jumlah penduduk yang semakin pesat maka semakin banyak pula masyarakat yang memerlukan air minum kemasan dari Perusahaan Air Minum Oasis Water International Cabang Palembang. Banyak juga perusahaan air minum lainnya yang bersaing untuk memenuhi kebutuhan air minum kemasan bagi masyarakat terutama di kota Palembang. Perusahaan yang mampu bersaing dan bertahan dalam persaingan

\begin{tabular}{lll}
\hline Artikel masuk & $:$ & 04 November 2017 \\
Artikel direvisi & $:$ & 18 November 2017 \\
Artikel diterima & $:$ & 18 November 2017
\end{tabular}

tentu di dukung dengan sumber daya yang berkompeten dan mampu melaksanakan visi dan misi perusahaan dengan baik

Produktivitas merupakan rasio output terhadap input sumber daya yang digunakan juga dapat diartikan sebagai rasio antara output terhadap input sumber daya yang dipakai (Sulaeman, 2014). Secara defenisi kerja, produktivitas merupakan perbandingan antara hasil yang dicapai (keluaran) dengan keseluruhan sumber daya (masukan) yang dipergunakan persatuan waktu. Defenisi kerja ini mengandung cara atau metode pengukuran. produktivitas mengandung pandangan hidup dan sikap mental yang selalu berusaha untuk meningkatkan mutu kehidupan (Devi, 2009). 
Banyak faktor-faktor yang mempengaruhi tingkat produktivitas kerja karyawan. Faktor yang berhubungan dengan kondisi karyawan ataupun kebijakan perusahaan. Dalam penelitian ini difokuskan tingkat produktivitas yang berhubungan dengan kondisi karyawan.

Salah satu faktor yang mempunyai pengaruh terhadap produktivitas karyawan adalah faktor usia (Tanto et,al (2012), \& Mahendra \& Woyanti (2014)). Usia yang masih dalam masa produktif biasanya mempunyai tingkat produktivitas lebih tinggi dibandingkan dengan tenaga kerja yang sudah berusia tua sehingga fisik yang dimiliki menjadi lemah dan terbatas.

Faktor-faktor yang mempengaruhi produktivitas seseorang dalam bekerja adalah lama bekerja (Nainggolan et,al (2012), Wirawan, et,al (2014), \& Pamungkas et,al (2017)). seseorang dalam bekerja adalah lama bekerja. Semakin lama masa kerja seorang tenaga kerja seharusnya keterampilan dan kemampuan melakukan pekerjaan semakin meningkat. Pengalaman seseorang melaksanakan pekerjaan secara terus menerus mampu meningkatkan kedewasaan teknisnya. Masa kerja adalah tingkat penguasaan seseorang dalam pelaksanaan aspek-aspek teknik peralatan dan teknik pekerjaan. Ada beberapa yang menentukan berpengalaman tidaknya seseorang karyawan dan sekaligus sebagai indikator pengalaman kerja yaitu lama waktu / usia kerja, tingkat pengetahuan dan keterampilan dan penguasaan terhadap pekerjaan dan peralatan.

PT. Oasis Water International untuk cabang Palembang memiliki 4 orang supervisor, 2 orang koordinator dan seorang manager HRD. Untuk kantor cabang yang terletak di Jalan Talang Kelapa, Alang-Alang Lebar Palembang memiliki jumlah pegawai sebanyak 35 orang yang terbagi atas 7 bagian. Dengan jumlah karyawan paling banyak pada unit pengepakan.

Berdasarkan survei awal yang dilakukan oleh peneliti, masih ditemukannya beberapa karyawan yang sulit terpusat pada pekerjaannya terutama pada unit pengepakan, hal ini cukup menggangu efektivitas dari perusahaan. Produktivitas kerja karyawan masih belum optimal, terlihat dari jumlah hasil kerja bagian pengepakan yang terhitung setiap jamnya. Hal ini walaupun terlihat biasa saja, tapi akan berdampak pada produktivitas perusahaan yang tidak optimal dan tidak sesuai target perusahaan yang diinginkan.

Berdasarkan latar belakang di atas, maka peneliti melakukan penelitian untuk mengetahui ada tidaknya pengaruh usia dan masa kerja terhadap produktivitas kerja karyawan di Perusahaan Air Minum Oasis Water International Cabang Palembang

\section{METODE PENELITIAN}

Penelitian dilaksanakan pada perusahaan Oasis Water Internasional Cabang Palembang, Jalan Talang Kelapa, Alang-alang Lebar. Proses penelitian ini dilakukan dari bulan Februari sampai Maret 2017.

Tinggi rendahnya kualitas karyawan akan mempengaruhi kinerja untuk meningkatkan hasil outputnya dalam pekerjaan, yang akan mempengaruhi produktivitas kerjanya. Sejalan dengan pernyataan di atas dan penelitian yang telah dilakukan sebelumnya, maka dalam penelitian ini produktivitas kerja karyawan dipengaruhi oleh faktor usia dan masa kerja karyawan PT. OWI Cabang Palembang.

Variabel penelitiannya terdiri dari usia (X1), masa kerja (X2) dan produktivitas Kerja (Y). Variabel tersebut sebagai variabel independen/bebas (X) dan bersama-sama dengan variabel dependen/terikat (Y) diukur dengan alat analisis regresi linear berganda untuk mendapatkan signifikansinya. Untuk memperjelas pengaruh usia (X1) dan masa kerja (X2) terhadap produktivitas kerja karyawan( $\mathrm{Y})$ dapat dilihat dalam gambar 1 sebagai berikut :

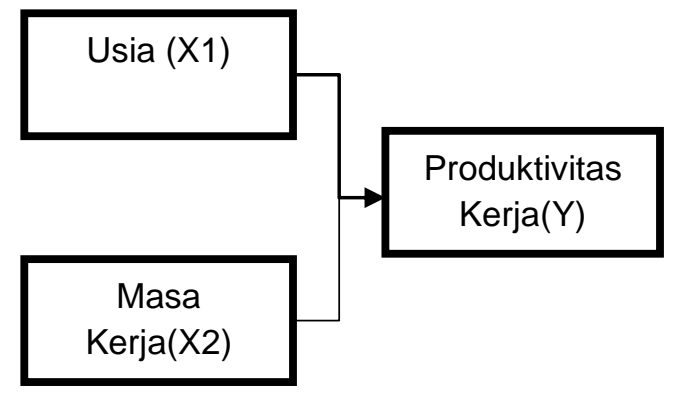

Gambar 1 Kerangka Pemikiran Penelitian

Populasi dalam penelitian ini adalah karyawan PT. Oasis Water International Cabang Palembang pada unit pengepakan. Metode sampling yang digunakan teknik random sampling. Adapun sampel yang diamati dalam penelitian ini adalah karyawan dengan masa kerja lebih dari 2 tahun serta masih dalam usia produktif yaitu antara umur 20 - 40 tahun.

Metode pengumpulan data disesuaikan dengan pokok permasalahan yang sedang di teliti, situasi dan kondisi serta keakuratan yang diharapkan. Dalam penelitian ini menggunakan metode wawancara dengan cara tanya jawab dengan cara mempersiapakan sejumlah 
pertanyaan yang terstruktur kepada responden yang mewakili karakteristik karyawan dengan masa kerja lebih dari 2 tahun dan rentang usia produktif antara 20-40 tahun.

Variabel penelitian merupakan variasai atau atribut tertentu yang telah ditetapkan dalam penelitian yang akan dipelajari dan ditarik kesimpulan (Sugiyono, 2008). Variabel penelitian dibagi menjadi dua, yaitu variabel independen dan variabel dependen. Variabel independen adalah tipe variabel yang mempengaruhi variabel terikatnya (Aryani \& Rosinta, 2011). Variabel dependen adalah tipe variabel yang dijelaskan atau dipengaruhi oleh variabel independen. (Indriantoro \& Supomo, 1999).

Analisis data digunakan regresi linier berganda (multiple regression) dan dilakukan dengan bantuan program aplikasi SPSS. Berdasarkan model regresi dapat dilakukan beberapa Uji-t dan Uji F, Uji-t ini untuk mengetahui ada atau tidaknya pengaruh parsial (sendiri) yang diberikan variabel bebas $(X 1, X 2)$ secara individu terhadap variabel terikat (Y). Sedangkan Uji $F$ bertujuan untuk mengetahui ada atau tidaknya pengaruh simultan (bersamasama) yang diberikan variabel bebas (X1 dan $\mathrm{X} 2)$ terhadap variabel terikat (Y). (Sudjana, 2005).

Uji $\mathrm{t}$ dilakukan dengan membandingkan nilai t hitung dengan $t$ tabel. Dimana jika nilai sig $<0,05$ atau $t_{\text {hitung }}>t_{\text {tabel }}$ maka terdapat pengaruh variabel $X$ terhadap variabel $Y$, sedangkan jika nilai sig $>0,05$ atau $t$ hitung $<t$ tabel maka tidak terdapat pengaruh variabel $X$ terhadap variabel $Y$ ( $n$ : jumlah sampel ; k: jumlah variabel bebas). Untuk menghitung nilai $\mathrm{t}$ tabel menggunakan persamaan (1) :

$t_{\text {tabel }}=t(\alpha / 2 ; n-k-1)=t(0,025 ; 24)=2,064$

Uji $F$ dilakukan dengan membandingkan nilai $F$ hitung dengan nilai $F$ tabel. Dimana jika nilai sig $<0,05$ atau $F$ hitung $>F$ tabel maka terdapat pengaruh variabel $X$ secara simultan terhadap variabel Y.sedangkan jika nilai sig $>0,05$ atau $F$ hitung $<F$ tabel maka tidak terdapat pengaruh variabel $X$ secara simultan terhadap variabel $Y$. Untuk menghitung $\mathrm{F}$ tabel menggunakan persamaan (2):

$F_{\text {tabel }}=F(k ; n-k)=F(2 ; 25)=3,39$

Koefisien determinasi $\left(\mathrm{R}^{2}\right)$ digunakan untuk mengetahui persentase variabel bebas secara bersama-sama dapat menjelaskan variabel terikat. Nilai koefisien determinasi adalah di antara nol dan satu. Jika koefisien determinasi $\left(R^{2}\right)=1$, artinya variabel bebas memberikan semua informasi yang dibutuhkan untuk memprediksi variasi variabel terikat. Jika koefisien determinasi $\left(R^{2}\right)=0$, artinya variabel bebas tidak mampu menjelaskan variasi-variasi terikat.

\section{HASIL DAN PEMBAHASAN}

Data penelitian ini berdasarkan hasil koresponden diperoleh data Sebanyak 27 karyawan pada unit pengepakan PT. Oasis Water International Cabang Palembang yang memenuhi kriteria yang dikelompokkan sesuai dengan karakteristik usia masa produktif kisaran 20-40 tahun dan masa kerja lebih dari 2 tahun

Tabel 1. Data Hasil Koresponden berdasarkan tingkat produktivitas kerja

\begin{tabular}{lllll}
\hline No & $\begin{array}{c}\text { Produktivitas } \\
\text { kerja } \\
\text { (dus/menit) }\end{array}$ & $\begin{array}{l}\text { Jumlah } \\
\text { Orang }\end{array}$ & $\begin{array}{l}\text { Usia } \\
\text { (tahun) }\end{array}$ & $\begin{array}{l}\text { Masa } \\
\text { Kerja } \\
\text { (tahun) }\end{array}$ \\
\hline 1 & 1,667 & 10 & $20-30$ & $2-3$ \\
\hline 2 & 1,650 & 6 & $20-30$ & $3-4$ \\
\hline 3 & 1,630 & 6 & $30-40$ & $3-4$ \\
\hline 4 & 1,616 & 5 & $20-30$ & $2-3$ \\
\hline
\end{tabular}

Tabel 2. Hasil Uji t Regresi

\begin{tabular}{|c|c|c|c|}
\hline \multicolumn{4}{|c|}{ Coefficients $^{\mathrm{a}}$} \\
\hline & Model & $\mathrm{t}$ & Sig. \\
\hline \multirow{3}{*}{1} & (Constant) & 1,228 & ,000 \\
\hline & $\mathrm{X} 1$ & 1,228 & ,000 \\
\hline & $\mathrm{X} 2$ &,- 198 & ,231 \\
\hline
\end{tabular}

Dari hasil $t$ sesuai dengan tabel 2 diperoleh a. Nilai sig. untuk pengaruh $\mathrm{X} 1$ terhadap $Y$ adalah sebesar $0,231>0,05$ dan nilai $t$ hitung $1,228<t$ tabel 2,064, sehingga dapat dikatakan bahwa faktor usia tidak berpengaruh terhadap produktivitas kerja di PT. Oasis Water International cabang Palembang karena rata-rata usia karyawan masuk dalam standar produktif kerja.

Usia yang masih memasuki masa produktif antara 20 sampai 40 tahun dalam penelitian ini tidak mempunyai pengaruh yang signifikan terhadap produktivitas kerja yang diperoleh. Kemampuan karyawan secara keseluruhan pada usia produktif hampir sama. Selain itu juga dipengaruhi dengan jenis pekerjaan yang tidak terlalu rumit sehingga tidak memerlukan skill khusus.

Nilai sig. untuk pengaruh $X 2$ terhadap $Y$ adalah sebesar $0,845>0,05$ dan nilai $t$ hitung $0,198<\mathrm{t}$ tabel 2,064, sehingga dapat dikatakan bahwa masa kerja juga tidak berpengaruh terhadap produktivitas kerja karyawan PT. Oasis Water International cabang palembang karena 
rata-rata karyawan memiliki masa kerja yang tidak jauh selisihnya.

Pengalaman kerja dalam penelitian ini tidak mempunyai pengaruh yang signifikan dikarenakan perbedaan masa kerja yang beda setahun sehingga skill yang diperoleh hampir sama. Hal ini berbeda dengan yang dilakukan Amron (2015), dimana dengan rentang pengalaman 5 bulan sampai 5 tahun mempunyai pengaruh terhadap produktivitas kerja karyawan.

Berdasarkan uji $F$ yang dilakukan, diperoleh hasil bahwa usia (X1) dan masa kerja (X2) tidak memiliki pengaruh positif secara simultan terhadap produktivitas kerja $(\mathrm{Y})$. Hal ini berdasarkan nilai sig 0,355 > 0,05. Rentang perbedaan yang dekat menyebabkan usia dan pengalaman kerja tidak mempunyai pengaruh yang signifikan terhadap peningkatan produktivitas kerja.

Tabel 3. Hasil Uji F Regresi Linear

\begin{tabular}{llccc}
\hline \multicolumn{5}{c}{ ANOVA $^{\text {a }}$} \\
\hline Model & $\begin{array}{c}\text { Sum of } \\
\text { Squares }\end{array}$ & $F$ & Sig. \\
\hline \multirow{2}{*}{1} & Regression &, 000 & 1,083 &, $355^{\mathrm{b}}$ \\
\cline { 2 - 5 } & Residual &, 002 & & \\
\cline { 2 - 5 } & Total &, 003 & & \\
\hline
\end{tabular}

Tabel 4. Hasil Uji $R$ Square

\begin{tabular}{ccccc}
\hline \multicolumn{5}{c}{ Model Summary } \\
\hline Model & $\mathrm{R}$ & $\begin{array}{c}R \\
\text { Square }\end{array}$ & $\begin{array}{c}\text { Adjusted } \\
R \text { Square }\end{array}$ & $\begin{array}{c}\text { Std. Error } \\
\text { of the } \\
\text { Estimate }\end{array}$ \\
\hline 1 &, $288^{\mathrm{a}}$ &, 083 &, 006 &, 00981
\end{tabular}

Berdasarkan output diatas diketahui nilai $R$ square sebesar 0,083, nilai ini menyatakan bahwa pengaruh variabel X1 (Usia) dan X2 (masa kerja) secara simultan terhadap variabel $Y$ (produktivitas kerja) adalah sebesar 8,3\% dan sisanya $91,7 \%$ dipengaruhi oleh faktor lain diluar variabel penelitian. Usia karyawan yang masih dalam masa produktif dan rentang pengalaman kerja yang tidak jauh menyebabkan faktor usia an masa kerja mempunyai pengaruh yang sedikit terhadap produktivitas kerja.

Penyebab kesulitan karyawan dalam mencapai produktivitas kerja yang diharapkan banyak disebabkan faktor-faktor diluar penelitian ini. Penelitian ini dapat dilanjutkan mencari faktor-faktor yang mempunyai pengaruh terhadap produktivitas kerja seperti lingkungan kerja, proses kerja, posisi kerja karyawan maupun kondisi organisasi perusahaan.

\section{KESIMPULAN}

Berdasarkan hasil penelitian terhadap karyawan perusahaan air minum PT. Oasis Water International cabang Palembang pada unit pengepakan dapat disimpulkan bahwa faktor usia dan masa kerja karyawan tidak begitu mempengaruhi tingkat produktivitas kerja karyawan. Faktor usia dan masa kerja karyawan hanya memiliki pengaruh sebesar $8,3 \%$ terhadap produktivitas diperusahaan tersebut

\section{DAFTAR PUSTAKA}

Amron, T. I. (2015). Analisis Faktor-Faktor yang Berpengaruh Terhadap Produktivitas Tenaga Kerja pada Outlet Telekomunikasi Seluler Kota Makasar. Skripsi, Fakultas Ekonomi dan Bisnis, Universitas Hasanudin.

Aryani, D., \& Rosinta, F. (2011). Pengaruh kualitas layanan terhadap kepuasan pelanggan dalam membentuk loyalitas pelanggan. Jurnal IImu Administrasi Dan Organisasi, 17(2), 114-126.

Devi, E. K. D. (2009). Analisis Pengaruh Kepuasan Kerja Dan Motivasi Terhadap Kinerja Karyawan Dengan Komitmen Organisasional Sebagai Variabel Intervening (Studi Pada Karyawan Outsourcing PT Semeru Karya Buana Semarang). Doctoral dissertation, Program Pasca Sarjana, Fakultas Ekonomika dan Bisnis, Universitas Diponegoro.

Indriantoro, N., \& Supomo, B. (1999). Metodologi Penelitian Bisnis untuk Akuntansi dan Manajemen. Yogyakarta: BPFE.

Mahendra, A. D., \& Woyanti, N. (2014). Analisis Pengaruh Pendidikan, Upah, Jenis Kelamin, Usia dan Pengalaman Kerja Terhadap Produktivitas Tenaga Kerja (Studi di Industri Kecil Tempe di Kota Semarang). Doctoral dissertation, Fakultas Ekonomika dan Bisnis, Universitas Diponegoro.

Nainggolan, R., Purwoko, A., \& Yuliarso, M. Z. (2012). Faktor-Faktor Yang Mempengaruhi Produktivitas Tenaga Kerja Pemanen Sawit Pada PT. Bio Nusantara Teknologi, Bengkulu. Jurnal Agrisep, 11(1), 35-42.

Pamungkas, A. D. P., Hamid, D., \& Prasetya, A. (2017). Pengaruh Pendidikan dan Pengalaman Kerja Terhadap Kemampuan Kerja dan Kinerja Karyawan (Studi pada Karyawan PT. INKA (Persero)). Jurnal Administrasi Bisnis, 43(1), 96-103.

Sudjana, N. (2005). Metode statistika. Bandung: Tarsito.

Sugiyono. (2008). Metode Penelitian Bisnis. Bandung: CV. Alfabeta. 
Sulaeman, A. (2014). Pengaruh Upah dan Pengalaman Kerja Terhadap Produktivitas Karyawan Kerajinan Ukiran Kabupaten Subang. TRIKONOMIKA, 13(1), 91-100.

Tanto, D., Dewi, S. M., \& Budio, S. P. (2012). Faktor-Faktor Yang Mempengaruhi Produktivitas Pekerja Pada Pengerjaan Atap Baja Ringan Di Perumahan Green Hills Malang. Rekayasa Sipil, 6(1), 69-82.

Wirawan, K. E., Bagia, I. W., Si, M., \& Susila, G. P. A. J. (2014). Pengaruh Tingkat Pendidikan dan Pengalaman Kerja Terhadap Kinerja Karyawan. Jurnal Jurusan Manajemen, 4(1), 1-10. 